\title{
Principles, Theories and Approaches to Critical Discourse Analysis
}

\author{
Franck Amoussou ${ }^{1}$, Ayodele A. Allagbe ${ }^{2 *}$ \\ ${ }^{1}$ Département d'Anglais, Faculté des Lettres, Langues, Arts et Communication (FLLAC) Université d'Abomey- \\ Calavi (UAC) Benin. \\ ${ }^{2}$ Laboratory for Research in Linguistics and Literature (LabReLL)
}

*Corresponding Author: Ayodele A. Allagbe, Laboratory for Research in Linguistics and Literature (LabReLL), Benin

\begin{abstract}
Critical Discourse Analysis (hereafter CDA) is a cross-discipline set forth in the early 1990s by a group of scholars such as Theo van Leeuwen, Gunther Kress, Teun van Dijk, and Norman Fairclough (Wodak \& Meyer, 2001). Since the last decade or so, there has been a resurgence of the application of the theory of CDA to a range of studies (Bloor \& Bloor, 2007; Bayram, 2010; Jahedi \& Abudullah, 2012; Parham, 2013; Akogbeto \& Koukpossi, 2015; Koussouhon \& Dossoumou, 2015; Koussouhon \& Amoussou, 2016; etc.).In view to spurring on the use of that research paradigm, the current study attempts to clarify what it means to say that one is doing critical discourse analysis. In that endeavor, it sheds light on the principles underlying the concept, the methods it draws on, as well as the focal approaches to CDA that have thus far been put forth by prominent scholars.
\end{abstract}

Keywords: Approach, Critical Discourse Analysis, Discourse Analysis, Paradigm, Theory.

\section{INTRODUCTION}

Critical Discourse Analysis (hereafter CDA) is a cross-discipline set forth in the early 1990s by a group of scholars such as Theo van Leeuwen, Gunther Kress, Teun van Dijk, and Norman Fairclough (Wodak \& Meyer, 2001). At that time, theories and methods of CDA have been formulated to differentiate this paradigm from other theories and methodologies in Discourse Analysis. Later on, the term has been known under many designations. While, according to their fields of research or areas of study, some scholars prefer the concept Critical Linguistics (CL), others choose to use the label Critical Discourse Studies (CDS). It follows from this to argue that CDA is an interdisciplinary approach which, as stated by Bloor and Bloor (2007), can be used by professionals from a variety of backgrounds such as historians, business institutions, lawyers, politicians, etc., to investigate social problems relating to their work.

Since the last decade or so, there has been a resurgence of the application of the theory of CDA to a range of studies (Bloor \& Bloor, 2007; Bayram 2010; Jahedi \& Abudullah 2012; Parham, 2013; Akogbeto \& Koukpossi, 2015;Koussouhon \& Dossoumou, 2015, Koussouhon \& Amoussou, 2016; to name but a few). Although such research works provide the reader with valuable and pertinent results, some seem far from abiding by the elementary principles underlying the critical approach they set out to apply. In that sense, this research work intends to make it clear that a systematic application of some theories like Systemic Functional Linguistics to a text or discourse (as often recommended by CDA proponents) is not sufficient to claim the critical stance of the study of the text or discourse. As Wodak \& Meyer (2009) put it, there are "salient principles which are constitutive of all approaches in CDA" (p.1). The current endeavor attempts then to clarify what it means to say that one is doing critical discourse analysis. In that perspective, the following research questions are posed: what is CDA? Can any analysis of discourse, assuming that language is social and political, be considered as a CDA? To what extent does CDA differ from other types of discourse analysis? What aspects of language are important to analyze in conducting CDA? How do we assess the validity and trustworthiness of research on CDA? The subsequent sections will try to provide answers to these questions. 


\section{Features OF CDA}

This section is concerned with underlining the main tenets that characterize CDA. In that respect, it will first highlight the difference between CDA and other kinds of discourse analysis. Then, the basic assumptions of CDA are going to be highlighted.

\subsection{CDA and Other DA Approaches}

As may be guessed from the label of each of the two concepts, CDA and DA (Discourse Analysis) do not mean the same thing. DA is a series of interdisciplinary approaches that can be used to explore many different social domains in many different types of studies (Jørgensen and Phillips, 2002:12). This means that discourse analysis can be applied to all areas of research, with a method of analysis intrinsically linked to its theoretical and methodological foundations. Brown \& Yule (1983:26) argue that 'doing discourse analysis' involves not only 'doing syntax and semantics', but also 'doing pragmatics'. It follows from this that the context of occurrence of a piece of discourse should be of particular interest to the discourse analyst.

As for CDA, it "focuses on social problems, and especially on the role of discourse in the production and reproduction of power abuse or domination" (van Dijk, 2001:96). CDA, then, sets up a relationship between language and power. In that sense, Wodak (2001) regards it as fundamentally concerned with analyzing opaque as well as transparent structural relationships of dominance, discrimination, power and control as manifested in language.

Concerning the difference between CDA and DA, Rogers (2004:3) claims that CDA differs from other discourse analysis methods in that it includes not only a description and interpretation of discourse in context, but also offers an explanation of why and how discourses work.

Wodak (2001) claims that the differences between CDA and other DA, pragmatic and sociolinguistic approaches may be most clearly established with regard to the general principles of CDA. In that regard, Fairclough and Wodak (1997, cited in van Dijk, 1993) set forth eight foundational principles of CDA which, as viewed by Rogers (2004), "are a useful starting point for researchers interested in conducting CDA". These principles are underscored in the following subsection. But for the moment, it is expedient to explain what makes CDA critical, that is to elucidate the critical side of the concept.

In normal parlance, the word 'critical' denotes the habit of evaluating an object or situation in accordance with a system of rules, principles and values (Locke, 2004). Within CDA perspective, 'critical' is not to be understood in the common sense of the word, i.e., criticizing, or being negative. In a conversation best owed to Kendall Gavin, Wodak (2001) claims that 'critical' means not taking things for granted, opening up complexity, challenging reductionism, dogmatism and dichotomies, being self-reflexive in one's research, and through these processes, making opaque structures of power relations and ideologies manifest. 'Critical', thus, does not imply the common sense meaning of 'being negative'-rather 'skeptical'. Proposing alternatives is also part of being 'critical' (Kendall, 2007). Rogers (2004:3) believes that within this framework of 'critical', the analyst's intention is to uncover power relationships and demonstrate inequalities embedded in society.

\subsection{Basic Assumptions, Aims and Definition}

It is paramount to signal at the outset of this subsection that it is not easy to precisely delimit the special principles, practices, aims, theories or methods of CDA (Van Dijk, 1995). Yet, any research work which claims to be of the CDA paradigm should be characterized by some basic criteria. Those criteria, originally defined by Kress (1990), are taken further by Fairclough \& Wodak (1997) who establish some basic principles of a CDA programme (Cf. Wodak, 2001:5). Critical research on discourse, Van Dijk (2003) argues, needs to satisfy a number of requirements in order to effectively realize its aims:

- It is problem-or issue-oriented: any theoretical and methodological approach is relevant as long as it is able to successfully study relevant social problems such as sexism, racism, and other forms of social inequality;

- In order to study social problems or issues adequately, CDA work is typically inter- or multidisciplinary, and especially focuses on the relations between discourse and society;

- CDA does not characterize a school, a field or a sub-discipline of discourse analysis, but rather an explicitly critical approach, position, or stance of studying text and talk.

International Journal on Studies in English Language and Literature (IJSELL) 
- CDA especially focuses on (group) relations of power, dominance and inequality and the ways these are reproduced or resisted by social group members through text and talk;

- Much work in CDA is about the underlying ideologies, that play a role in the reproduction of or resistance against dominance or inequality;

- CDA studies are geared to uncovering, revealing or disclosing what is implicit, hidden or otherwise not immediately obvious in relations of discursively enacted dominance or their underlying ideologies. That is, CDA especially focuses on the strategies of manipulation, legitimation, the manufacture of consent and other discursive ways to influence the minds (and indirectly the actions) of people in the interest of the powerful;

- This attempt to uncover the discursive means of mental control and social influence implies a critical and oppositional stance against the powerful and the elites, and especially those who abuse of their power;

- On the other hand, studies in CDA try to formulate or sustain an overall perspective of solidarity with dominated groups, e.g., by formulating strategic proposals for the enactment and development of counter-power and counter-ideologies in practices of challenge and resistance.

As stated above, Fairclough \& Wodak (1997) draw on the aforementioned criteria and set up eight basic principles or tenets of CDA as follows: (i) CDA addresses social problems; (ii) power relations are discursive; (iii) discourse constitutes society and culture; (iv) discourse does ideological work; (v) discourse is historical; (vi) the link between text and society is mediated; (vii) discourse analysis is interpretative and explanatory; (viii) discourse is a form of social action (cf. Van Dijk, 1995:353; Jahedi, Abdullah \&Mukundan, 2014:29).

Based on those characteristics or distinguishing features, Wodak (2001) contends that CDA aims to investigate critically social inequality as it is expressed, signaled, constituted, legitimized and so on by language use (or in discourse). As for Meyer (2001), CDA aims to make transparent the discursive aspects of societal disparities and inequalities. Fairclough (1992:315, cited in Min 1997:148) states the objectives of CDA in more practical terms when he postulates that the aims of CDA are to explore the social function of language, to describe linguistic processes in social terms, and to reveal the 'ideological' and political investments'. It follows from this to argue that in the attempt to investigate the social function of language (while doing CDA), one needs to make a description of linguistic properties so as to disclose or unravel the ideologies embedded in the discourse under study. In that regard, Widows on (2004) sustains that how language is used to construct social identity and social relationship [thus social inequality] is directly referable from linguistic forms.

In the light of the abovementioned aims, Fairclough (2001), defines CDA as "a form of critical social science geared to illuminating the problems which people are confronted with by particular forms of social life, and to contributing resources which people may be able to draw upon in tackling and overcoming those problems" (p.125). Van Dijk (2003) regards CDA as a type of discourse analytical research that primarily studies the way social power abuse, dominance and inequality are enacted, reproduced, and resisted by text and talk in the social and political context. For Kazemian \& Hashemi (2014), CDA is an interdisciplinary analytical viewpoint which looks into the relationship between power and discourse, and particularly it investigates the way in which authority, dominance and social inequality are constructed, sustained, reproduced and resisted in the discourse of written texts and spoken words. Fairclough (1995) rather provides a quite lengthy definition to the concept:

By critical discourse analysis I mean analysis which aims to systematically explore often opaque relationships of causality and determination between (a)discursive practices, events and texts, and (b) wider social and cultural structures, relations and processes; to investigate how such practices, events and texts arise out of and are ideologically shaped by relations of power and struggles over power, and to explore how the opacity of these relationships between discourse and society is itself a factor securing power and hegemony (p.132-33).

From the above definitions, it should be inferred that some key concepts figure prominently in any work in CDA. These are 'power', 'dominance', 'hegemony', 'ideology', 'discrimination', 'social order', 'reproduction', 'resistance', 'struggle', etc. The next section will deal with the methods drawn upon by critical discourse analysts and the focal approaches they use. 


\section{METHODS OF AND APPROACHES TO CDA}

\subsection{Methods}

Research is regularly legitimized as scientific by means of intelligible methods (Meyer, 2001:14). Viewed as research pathways, methods are apprehended in CDA as a hermeneutic process. Hermeneutics, in Meyer (ibid)'s sense, means "the method of grasping and producing meaning relations" (p.16). With regard to its interdisciplinary feature, the description of the object of investigation of CDA is carried out from a widely differing perspective. This entails that CDA does not have its own specific methods different from other social studies. Rather, it shares, as Bloor \& Bloor (2007) put it, methods with disciplines that study social groups and social structures, such as anthropology, sociology, ethnography and ethno methodology, and with disciplines that are concerned with human cognition and behaviour, such as cognitive and social psychology.

According to Fairclough (1989), each of the many existing approaches to language (linguistics, sociolinguistics, pragmatics, cognitive psychology, conversation analysis, etc.) has something to contribute to CDA. However, Bloor \& Bloor (2007) clarify that which method or combination of methods is chosen depends on the choice of research question. This, in turn, depends partly on the nature of the social problem and partly on the disciplinary background of the analyst. It is clear from the foregoing that CDA is not a specific direction of research. It does not have a unitary theoretical framework or methodology. It is best grasped as a shared perspective encompassing a range of approaches.

\subsection{Central Approaches to CDA}

There is a range of approaches to CDA. Among them we will outline those of three prominent scholars. These are Fairclough, Van Dijk, and Wodak.

\subsubsection{Fairclough's Socio-Cultural Approach}

Like the functional analysis of Halliday (1994, 2004, 2014), Fairclough's sytem of discourse analysis has three dimensions, since discourse is seen simultaneously as: (i) a text (spoken or written, including visual images), (ii) a discourse practice production, consumption and distribution of the text, and (iii) a socio cultural practice. Subsequently, Fairclough provides a three-dimensional framework for the analysis of text and discourse: (a) the linguistic description of the formal properties of the text; (b) the interpretation of the relationship between the discursive processes/interaction and the text, and finally, (c) the explanation of the relationship between discourse and social and cultural reality.

According to Fairclough, there are some underlying assumptions behind certain selections of discourse. These assumptions are never value-free and innocent; rather they are ideologically driven and motivated. Therefore, discursive practices may have ideological effects since they can produce and reproduce unequal power relations between social classes, gender groups and ethnic and cultural majorities and minorities through the ways they represent things and position people. From this point of view, Fairclough (1989) argues that "the exercise of power, in modern society, is increasingly achieved through ideology". Drawing on the discourse-power-ideology relationship, he introduces the concept of hegemony which he defines as "a way of theorizing change in relation to the evolution of power relations which allows a particular focus upon discursive change, but at the same time a way of seeing it as contributing to and being shaped by wider processes of change" (Fairclough, 1993:92 cited in Jahedi et al, 2014:30). For him, "the political concept of 'hegemony' can be usefully employed in analysing orders of discourse" (Fairclough, 2001, p.124). He then states that "an order of discourse is a network of social practices in its language aspect. The elements of orders of discourse are not things like nouns and sentences (elements of linguistic structures), but discourses, genres and styles" (Fairclough, 2003, p.24).

He further contends that orders of discourse are not static, but may change over time. Changing the power relations in a social interaction determines these changes. Fairclough then asserts that:

How discourses are structured in a given order of discourse, and how structurings change over time, are determined by changing relationships of power at the level of the social institution or of the society. Power at these levels includes the capacity to control orders of discourse; one aspect of such control is ideological-ensuring that orders of discourse are ideologically harmonized internally or (at the societal level) with each other (Fairclough, 2001, p.25). 


\subsubsection{Van Dijk's Socio-Cognitive Approach}

In accordance with Fairclough's critical approach, the socio-cognitive approach put forth by Van Dijk perceives discourse as a form of social practice. However, it does not focus on discursive practice. Van Dijk rather concentrates on social cognition as the mediating part between text and society. $\mathrm{He}$ claims that CDA needs to account for the various forms of social cognitions that are shared by the social collectivities (groups, organizations and institutions) (Van Dijk, 2001). Social cognitions, he states, are "socially shared representations of societal arrangements, groups and relations, as well as mental operations such as interpretation, thinking and arguing, inferencing and learning" (Van Dijk, 1993, p.257). Van Dijk further identifies two levels of (discourse) analysis: macro vs. micro. Language use, discourse, verbal interaction and communication determine the micro level of social order, while the macro level refers to power, dominance and inequality between social groups (Van Dijk, 2003).

Moreover, the approach of CDA Van Dijk (2000a, cited in Jahedi et al, 2014) adopts is based on understanding ideological structures and social relations of power embedded in discourse. He defines 'social power' in terms of control (Van Dijk, 2003) and views ideologies as "the basis of the social representations of groups" (Van Dijk, 2006:131). He therefore argues that "groups have (more or less) power if they are able to (more or less) control the acts and minds of (members of) other groups" (Van Dijk, 2003:354-5). Furthermore, he emphasizes that ideological discourse is generally organized by a general strategy of positive self-presentation (boasting) and negative other-presentation (derogation) (ibid).

In sum, Van Dijk claims that CDA should not limit itself to a study of the relationship between discourse and social structure, but that language use and discourse always presuppose the intervening mental models, goals and general social representations (knowledge, attitudes, ideologies, norms, values) of the language users. In other words, the study of discourse triangulates between society/culture/situation, cognition and discourse/language. This is the tripartite discourse-cognitivesociety model of ideology that backs up Van Dijk's socio-cognitive approach. As is obvious from most of Van Dijk's studies, his critical analysis of texts tends to make explicit the ideological dimension of 'Us' versus 'Them' and to demonstrate the discursive structures and strategies used in exercising the dominant power.

\subsubsection{Wodak's Discourse-Historical Approach}

Like Fairclough's and Van Dijk's approaches, Wodak's discourse-historical approach views discourse as a form of social practice. Wodak (2002, cited in Todolí et al, 2006;20) has focused on the interdisciplinary and eclectic nature of CDA, since problems in our society are too complex to be studied from a single point of view. Thus, to understand and explain the object under investigation, one needs to integrate diverse theories and methods. She thus contends that "studies in CDA are multifarious, derived from quite different theoretical backgrounds, oriented towards different data and methodologies" (Wodak, 2001:5).

One important tenet of CDA is "that all discourses are historical and can therefore only be understood with reference to their context" (Wodak, 2009:20; Meyer, 2001:15). This means that discourse is connected synchronically and diachronically with other communicative events which are happening at the same time or which have happened before. For Wodak, the notion of context is crucial for CDA, since this explicitly includes socio-psychological, political and ideological components and thereby postulates an interdisciplinary procedure.

Summarizing some important research agendas which are currently of interest in CDA, Wodak (2001:11) states that identity politics on all levels always entails the integration of past experiences, present events and future visions in many domains of our lives. This involves analyzing, understanding and explaining the relationship between complex historical processes, hegemonic narratives and CDA approaches. For the analysis of the interrelationship between discursive and other social practices and structures, Wodak (2001) refers to the principle of triangulation. This principle implies different methods of collecting data because in CDA, "there is no typical way of collecting data" (Meyer, 2001:23). After reviewing these theoretical and methodological approaches, it is now time to seek to know how to do CDA. 


\section{How to do CRitiCAL Discourse ANALYSIS?}

At this stage of our current research endeavour, the crucial question that deserves an answer is "How is critical discourse analysis done or undertaken? To that question, Van Dijk (1995) answers that the analyst "need" [s] first and foremost "to explore which structures and strategies of text and talk to attend in order to discover patterns of elite dominance or manipulation 'in' texts" (p.19). In other words, the discourse analyst should "detail how such forms of inequality are expressed, enacted, legitimated and reproduced by text and talk" (ibid). In practical terms, CDA proponents generally suggest reference to linguistic theories. In that perspective, Van Dijk (2001:97) assumes that explicit CDA needs a solid 'linguistic' basis, where 'linguistic' is understood in a broad 'structural-functional' sense. It follows from this to argue that Systemic Functional Linguistics (SFL) plays a crucial role in critical discourse study. As claimed by Kazemian \& Hashemi (2014), "strong interdisciplinary bonds exist between SFL and CDA" (p.1179). Endorsing that claim, Widdowson (2004) asserts that CDA generally takes its descriptive bearings from Systemic Functional Grammar, while Fairclough (2003) sustains that SFL is "a valuable resource for CDA, and indeed major contributions to CDA have developed out of SFL" (p.5). As a matter of fact, SFL is a linguistic theory that views and examines "language as shaped (even in its grammar) by the social functions it has come to serve" (Wodak, 2009:27). It should be recalled, on the other hand, that CDA addresses the prevailing social problems by opposing dominant ideological positions. The dialectical relationship between CDA and SFL becomes thus more than obvious. However, as stated earlier, a critical discourse analyst needs to resort not just to one method, but to a range of methods. This means that the linguistic approach should be combined with historical, socio-political, sociological, anthropological, sociolinguistic, etc., perspectives. In that sense, Fairclough (1989, 1992, 1995), Huckin (1997, cited in Todoli, et al, 2006) and Van Dijk (1997, cited in Rahimi, \& Riasati, 2011) raise several questions to guide text analysis on:

- Transitivity: what patterns of transitivity are found? Who is depicted as Agent (and therefore empowered), and over whom (the affected)? What is the degree of nominalization? How does it background the process itself by omitting information about agents of power? Do passive verbs also delete agents of power? What is the ideological function?

- Mood and Modality: How is mood enacted? Declarative, imperative, or interrogative? Which values express choices of modality?

- Vocabulary: How are words used to show ideology? What aspects of reality are overworded? How are overwording, synonymy, antonymy and hyponymy used to construct ideology? Are there euphemisms or metaphors? What connotations do they convey?

- Interactional control features: Which are the interactional control features of the text? Turntaking? Control of topics? Topic change? Opening and closing of interactions?

- Topicality: Which topics are chosen to fill theme position in the clause (initial position) or which are foregrounded?

- Presuppositions: Are there presuppositions or assumptions made by a speaker or writer which are not explicitly stated and which the author appears to take for granted?

- Vagueness: Which expressions are unclear because they do not give enough information or they do not say exactly what they mean?

- Implication: Which implicit information can be deduced or inferred from discourse on the basis of pragmatic contexts?

\section{Conclusion ANd Perspectives}

The principles of CDA as stated by scholars provide the major traits of an approach that distinguishes it quite well from other work on analysis of discourse. As a matter of fact, they proffer insights into the different features that help identify a work under the caption of critical discourse analysis. In addition, the theories underlying research on CDA give the analysts (be they lay researchers or not) a broad view on the possible methodological approaches they are liable to use, given their disciplinary backgrounds. Finally, the patterns of critical analysis pointed out at the last part of the present paper may, we believe, constitute a guide (not a panacea) to everyone who seeks to undertake a study on 
CDA or Critical Linguistic Analysis. Our wish is to arouse, through this study, students' (as well as other researchers') interest in giving a critical impetus to their research on Systemic Functional Theory. This will actually make their findings and conclusions more plausible and more valuable. As stated by Van Dijk (1995), "successful CDA must be effective: its conclusions, recommendations and other practical interventions must work. However, the current scholarship, as can be noticed, is basically theoretical. This requires that the researchers carry out a practical CDA on a concrete text or discourse. This will be the concern of Amoussou \& Amoussou (forthcoming).

\section{REFERENCES}

[1] Amoussou, Y. C. \& Amoussou, F. (forthcoming). Patriarchal Ideologies and Female Unfemininities in Contemporary Feminist Writings: A Gender-Oriented and Critical Discourse Analysis Perspective.

[2] Allagbé, A. A. \& Amoussou, F. (a, forthcoming). Patriarchal Ideologies and Female Unfemininities in Contemporary Feminist Writings: A Gender-Oriented and Critical Discourse Analysis Perspective.

[3] Allagbé, A. A. \& Amoussou, F. (b, forthcoming). Exploring Gender Issues In The Secret Lives of Baba Segi's Wives: A Critical Discourse Analysis Perspective.

[4] Bayram, F. (2010). Ideology and Political Discourse: A Critical Discourse Analysis of Erdogan's Political Speech. ARECLS, 7, 23-40.

[5] Bloor, M. \& Bloor, T. (2007). The Practice of CDA: An Introduction. Great Britain: Hodder Education.

[6] Brown, G. \& Yule, G. (1983). Discourse Analysis. Cambridge: Cambridge University Press.

[7] Fairclough, N. (1995). Critical Discourse Analysis: the critical study of language. London: Longman.

[8] Fairclough, N. (2001). Critical discourse analysis as a method in social scientific research. In R. Wodak \& M. Meyer (eds.), Methods of Critical Discourse Analysis (pp. 121-138). London: Sage.

[9] Fairclough, N. (2003). Analysing Discourse: Textual Analysis for social research. New York: Routledge.

[10] Jahedi, M. \& Abudullah, F. S. (2012). The Ideological Construction of Iran in The NYT. Australian Journal of Linguistics, 32 (3), 361-381.

[11] Jahedi, M., Abdullah, F. S. \& Mukundan, J. (2014). An Overview of Focal Approaches of Critical Discourse Analysis. International Journal of Education \& Literacy Studies, 2 (4), 28-35.

[12] Jørgensen, M. \& Phillips, L. (2002). Discourse Analysis as Theory and Method. London-Thousand OaksNew Delhi: Sage Publications.

[13] Kazemian, B. \& Hashemi, S. (2014). Critical Discourse Analysis of Barack Obama's 2012 Speeches: Views from SFL and Rhetoric. Theory and Practice in Language Studies, 4 (6), 1178-1187.

[14] Kendall, G. (2007). What is CDA? Ruth Wodak in Conversation With Gavin Kendal. Forum: Qualitative Social Research, 8 (2). Retrieved from http://nbn-resolving.de/wrn:nbn:de:0114-fqs 0702297, on August, $9^{\text {th }}, 2016$.

[15] Koussouhon, L. A. \& Amoussou, F. (2016). A Critical Discourse Analysis of Barak Obama's Speech on Climate Change. A paper submitted for Togo XVII colloquium held in Lome in October 2016.

[16] Koussouhon, L. A. \& Dossoumou, A. M. (2015). Political and Ideological Commitments: A Systemic Functioanl Linguistic and Critical Discourse Analysis of President Buhari's Inaugural Speech. International Journal of Linguistics and Communication, 3 (2), 24-34.

[17] Locke, T. (2004). Critical Discourse Analysis. London \& New York: Continuum International Publishing Group.

[18] Meyer, M. (2001). Between theory, method, and politics: positioning of the approaches to CDA. In R. Wodak \& M. Meyer (eds.), Methods of Critical Discourse Analysis (pp. 14-31). London: Sage.

[19] Min, J. S. (1997). Constructing Ideologies: A Critical Linguistic Analysis. Studies in the Linguistic Sciences, 27 (2), 147-165.

[20] Parham, F. (2013). Gender Representation in Children's EFL Textbooks. Theory and Practice in Language Studies, 3 (9), 1674-1679.

[21] Rahimi, F. \& Riasati, M. J. (2011). Critical Discourse Analysis: Scrutinizing Ideologically-Driven Discourses. International Journal of Humanities and Social Science, 1 (16), 107-112.

[22] Rogers, R. (2004). An Introduction to Critical Discourse Analysis in Education. London: Lawrence Erlbaum Associates, Inc.

[23] Todolí, J.; Labarta, M. \& Dolón, R. (2006). What is Critical Discourse Analysis? Quaderns de Filologia. Estudis Lingüistics, XI, 9-34.

[24] Van Dijk, T., A.(2001). Multidisciplinary Critical Discourse Analysis: A plea for diversity. In R.Wodak \& M. Meyer (eds.), Methods of Critical Discourse Analysis (pp. 95-120). London: Sage. 
[25] Van Dijk, T., A. (2003). Critical Discourse Analysis. In D. Schiffrin, D. Tannen, \& H. E. Hamilton (ed), The Handbook of discourse analysis (pp. 352-371). Maiden, MA: Blackwell.

[26] Van Dijk, T. A. (2006). Ideology and discourse analysis. Journal of Political Ideologies, 11 (2), 115-140.

[27] Widdowson, H. G. (2004). Critical discourse analysis. In H. G. Widdowson (ed). Text, Context, Pretext: Critical Issues in Discourse Analysis (pp. 89-111). Malden, MA: Blackwell Publishing Ldt.

[28] Wodak, R. (2001). What Critical Discourse Analysis is about-a summary of its history, important concepts and its developments. In R. Wodak \& M. Meyer (eds.), Methods of Critical Discourse Analysis (pp. 1-13). London: Sage.

[29] Wodak, R. (2009). Critical discourse analysis: history, agenda, theory, and methodology. In R. Wodak \& Meyer (eds), Methods of Critical Disocurse Analysis (pp. 1-33) $2^{\text {nd }}$ edition London: Sage.

[30] Wodak, R. \& Meyer, M. (2001). Methods of Critical Discourse Analysis. London: Sage.

\section{AUTHORS' BIOGRAPHY}

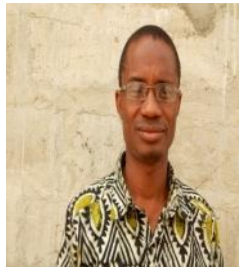

Franck Amoussou, is currently a $\mathrm{PhD}$ candidate at EDP/FLLAC/UAC (Benin). He is a Member of the Laboratory for Research in Linguistics and Literature (LabReLL) and Groupe de Recherche sur l'Afrique et la Diaspora (GRAD). He has co-authored some articles published locally and internationally. His fields of research encompass Systemic Functional Linguistics, Discourse Analysis, Critical Discourse Analysis, and Gender Representation in contemporary writings.

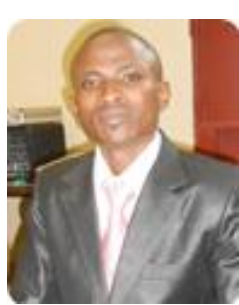

Ayodele Adebayo Allagbé, earned a Doctorate degree in English Applied Linguistics from the University of Abomey-Calavi, Republic of Benin, in 2015. He is a Member of Laboratory for Research in Linguistics and Literature (LabReLL) and Groupe de Recherche sur l'Afrique et la Diaspora (GRAD). He is also an author and a co-author of many papers published in prestigious local and international journals. His areas of interest include, but are not limited to, Systemic Functional Linguistics, Stylistics, Literary Criticism, Language Teaching and Pragmatics.

Citation: Franck Amoussou, Ayodele A. Allagbe " Principles, Theories and Approaches to Critical Discourse Analysis" International Journal on Studies in English Language and Literature (IJSELL), vol 6, no. 1, 2018, pp. 11-18. doi:http://dx.doi.org/10.20431/2347-3134.0601002.

Copyright: (C) 2018 Authors. This is an open-access article distributed under the terms of the Creative Commons Attribution License, which permits unrestricted use, distribution, and reproduction in any medium, provided the original author and source are credited. 